\title{
The microstructure and mechanical properties of Friction Stir Welded Cu-30Zn Brass Alloys
}

\author{
Y. F. Sun", N. Xu, H. Fujii \\ Joining and Welding Research Institute, Osaka University, Ibaraki 567-0046, Japan
}

\begin{abstract}
:
The optimized processing map for the friction stir welding of commercial $2 \mathrm{~mm}$-thick single phase $\mathrm{Cu}-30 \mathrm{Zn}$ brass alloy plates was obtained, which included a welding speed that ranged from 200 to 800 $\mathrm{mm} / \mathrm{min}$, a rotation speed that ranged from 750 to $1200 \mathrm{rpm}$ and a constant applied load of $1000 \mathrm{~kg}$. A remarkably refined microstructure was formed in the stir zone. The average grain size ranged from 6.4 to $9.6 \mu \mathrm{m}$ depending on the different welding conditions, which is much smaller than the $28.2 \mu \mathrm{m}$ of the base metal. Compared with the base metal, the dislocation cells, annealing twins with a smaller twin lamellar width, are easy to form in the stir zone. All the sound welds fractured on the base metal during the tensile tests, indicative of improved mechanical properties in the stir zone. Miniature tensile tests of the stir zone revealed that the highest tensile strength of the stir zone can reach about $380 \mathrm{MPa}$, much higher than the $340 \mathrm{MPa}$ of the base metal. The mechanism for the mechanical property improvement in the brass alloy joints are discribed and clarified from the viewpoint of microstructural evolution.
\end{abstract}

Keywords: Friction stir welding; Dynamic recrystallization; Mechanical properties; $\mathrm{Cu}$-Zn brass alloy

\footnotetext{
* Corresponding author: Yufeng Sun (Y.F. Sun), Email: yfsun@jwri.osaka-u.ac.jp; Tel:+81-6-68798653
}

$$
-1-
$$

(C) 2013. This manuscript version is made available under the Elsevier user license http://www.elsevier.com/open-access/userlicense/1.0/ 


\section{Introduction}

The most known $\mathrm{Cu}$-alloy is brass, i.e. $\mathrm{Cu}-\mathrm{Zn}$ alloys, which offer very useful properties, such as high strength, conductivity, formability, wear resistance and corrosion performance. The best combination of ductility and strength is obtained by the $\mathrm{Cu}-30 \mathrm{Zn}$ alloys, possessing an excellent deep drawability. However, several difficulties are encountered during the fusion welding of brass alloys, for example, change in color due to oxidation at higher temperature, insufficient penetration due to its high thermal conductivity, loss of strength in the fusion zone due to $\mathrm{Zn}$ evaporation and high distortion.

Friction stir welding (FSW) was invented at the The Welding Institute in 1991 [1], which was initially used to weld aluminum alloys. The FSW is a solid-state welding process and is performed at a much lower temperature than the melting point of the materials to be welded. Therefore, many problems that occur during the fusion welding process can be solved by FSW. This joining technique has merits of a low distortion, high quality and low cost, compared with those of the conventional fusion welding methods. Recently, the FSW technique has been significantly improved and can be used for many metallic materials including steel [2-4], Ti [5, 6], Al alloy composites [7, 8], etc. Nandan R [9] and Mishra RS [10] reviewed the FSW of some types of metallic materials and pointed out that FSW was certainly considered as the most suitable method for the welding of brass alloys. However, there are only a few reports concerning the applicability of this method to brass alloys. Meran C [11] may be one of the first people who carried out the FSW of $\mathrm{Cu}-\mathrm{Zn}$ plates. According to his study, the evaporation of $\mathrm{Zn}$ and the formation of pores in the welded region were completely prevented. The obtained welds can reach a strength the same as that of the base metal. Cam G et al. $[12,13]$ studied the effect of the FSW parameters on the tensile properties of $\mathrm{Cu}-10 \mathrm{Zn}$ and $\mathrm{Cu}-30 \mathrm{Zn}$ single phase and $\mathrm{Cu}-37 \mathrm{Zn}$ dual phase brass alloy plates. However, no detailed information on the microstructure evolution in the welded region was presented. Shortly after, Xie GM et al. $[14,15]$ investigated the FSW of a $\mathrm{Cu}-38 \mathrm{Zn}$ dual phase brass alloy and found that partial recrystallization existed in the stir zone, which is different from the study by Park et al. [16]. In Park's study, a homogeneous recrystallized structure was observed in the stir zone of the FSW processed dual phase brass alloy under a wide range of FSW parameters. Recently, Moghaddam MS et al. [17] studied the FSW of the $\mathrm{Cu}-30 \mathrm{Zn}$ brass alloy at various welding speeds and found that a "stir band" generally formed in the stir zone and the "stir band" had a significant influence on the mechanical properties of the obtained welds.

According to a few previous studies on the FSW of a $\mathrm{Cu}-\mathrm{Zn}$ brass alloy, the microstructural evolution in the stir zone varies in different studies and may be dependent on the welding parameters and the dimensions of 
the work-pieces. In this study, the FSW technique was applied to the welding of $2 \mathrm{~mm}$ thick single phase $\mathrm{Cu}-30 \mathrm{Zn}$ brass alloy plates under a fully-annealed condition. Various welding conditions within a wide range of welding speeds, tool rotation speeds and a constant applied load were tried using a load-controlled FSW machine in order to optimize the welding conditions for the FSW of a brass alloy. After welding, the relationship between the microstructural evolution and mechanical properties of the FSWed specimen were investigated and discussed.

\section{Experimental procedure}

Commercially pure $\mathrm{Cu}-30 \mathrm{Zn}$ brass alloy plates with the dimension of $200 \mathrm{~mm} \times 50 \mathrm{~mm}$ width $\times 2 \mathrm{~mm}$ thickness were subjected to the FSW process in this study, which were as-received in the fully-annealed state with an average grain size and tensile strength of about $28.2 \mu \mathrm{m}$ and $340 \mathrm{MPa}$, respectively. The brass alloy plates were first placed on a steel back plate and clamped tightly. The welding process was then performed using a load-controlled FSW machine. WC-based alloy tools, which had a $12 \mathrm{~mm}$-dia concaved shoulder, $4 \mathrm{~mm}$-dia unthreaded probe and $1.8 \mathrm{~mm}$ probe height, were used and tilted by $3^{\circ}$ during the welding process. To obtain the optimized welding conditions, various welding speeds from 200 to 800 $\mathrm{mm} / \mathrm{min}$, rotation speed from 750 to $1200 \mathrm{rpm}$ and a constant applied load of $1000 \mathrm{~kg}$ were used for the FSW of the brass alloy. To prevent oxidation of the stir zone, the FSW processes were carried out with argon gas continuously flowing around the rotating tools.

After welding, optical microscopy (OM) and electron backscattered diffraction (EBSD) measurements were used to characterize the macrostructure of the joints. The samples for the OM observation were cross-sectioned perpendicular to the welding direction, polished and then etched with a solution of iron chloride. The EBSD measurements were carried out using a JEM 5200 scanning electron microscope (SEM) with a TSL orientation imaging system. The microstructures in the stir zone as well as in the base metal were characterized by transmission electronic microscopy (TEM). For TEM sample preparation, thin plate were first cut from the desired locations and then mechanically polished to $100 \mu \mathrm{m}$. The polished thin

plates were finally twin-jet electro-polished to make electron beam transparent thin films using a solution of $\mathrm{HPO}_{4}: \mathrm{CH}_{4} \mathrm{O}: \mathrm{H}_{2} \mathrm{O}=1: 1: 2$ at $5 \mathrm{~V}$ and $0{ }^{\circ} \mathrm{C}$. The thin films were observed using a Hitachi 800 TEM at $200 \mathrm{kV}$. The tensile specimens were electrical discharge machined into a dog-bone shape with a gauge length of $100 \mathrm{~mm}$, width of $10 \mathrm{~mm}$ and thickness of $2 \mathrm{~mm}$. The tensile tests were carried out using an Instron-type testing machine with a crosshead speed of $1 \mathrm{~mm} / \mathrm{min}$. The tensile direction is perpendicular to 
the welding direction. For the miniature tensile tests, specimens were cut in a dog-bone shape with the gauge length of $6 \mathrm{~mm}$, width of $3 \mathrm{~mm}$ and thickness of $2 \mathrm{~mm}$. The gauge length was completely within the welded joint to evaluate the tensile strength.

\section{Experimental results and discussion \\ 3.1 Welding condition optimization}

In order to optimize the welding conditions for the FSW of the brass alloy, the FSW was performed over a wide range of welding parameters. As is well known, the FSW process can be performed due to the frictional heat generated between the rotating tool and the work-piece, and therefore, the quality of the friction stir welds is generally dependent on the amount of the frictional heat input. Fig. 1 shows three typical kinds of weld appearances that generally form during the FSW of the brass alloy, in which the defects formed in the brass welds are very similar to the welding defects formed in the FSW of Al alloys studied by Kim [18]. The heat input was adjusted by increasing the rotation speed. Fig. 1(a) shows the formation of a tunnel-like defect in the stir zone, which is caused by the introduction of insufficient heat into the work-piece. Fig. 1(b) is an example of sound welds, in which the surface is clean, regular and with little flash. However, Fig. 1(c) shows the sample welded with a redundant heat input. Superfluous flash was therefore formed and the thickness of the stir zone significantly decreased. Moreover, the distortion of the welds becomes worse due to the high temperature increase, which is indicated by a short arrow in the figure.

Fig. 2 shows the cross-sectional microstructure of the stir zone obtained under various welding conditions. Corresponding to the sample appearance shown in Fig. 1(a), generally three kinds of microstructure features were observed along the cross-sectional plane of the stir zone. One microstructural feature is the formation of tunnel-like defects, such as the sample welded at $200 \mathrm{~mm} / \mathrm{min}$ and $700 \mathrm{rpm}$ or $350 \mathrm{~mm} / \mathrm{min}$ and 800rpm, as shown in Fig. 2. It is worth noting that all the defects are formed on the advancing side of the stir zone. In this case, the material flow is not strong enough to fill the defects due to the insufficient heat input. Another one is the sound welds like those welded at $200 \mathrm{~mm} / \mathrm{min}$ and $750 \mathrm{rpm}$ or $350 \mathrm{~mm} / \mathrm{min}$ and 900rpm. No defects and little flash can be found. The third one is the superfluous flash formed around the stir zone like the one welded at $200 \mathrm{~mm} / \mathrm{min}$ and $850 \mathrm{rpm}$; too much flash indicated by an arrow in the figure formed during the FSW due to the high heat input. 
Based on the weld appearances and the cross-sectional microstructure characterization of the stir zone, the optimized welding parameters for the FSW of the brass alloy can be obtained as shown in Fig. 3. Sound welds can be obtained for the welding condition between the two solid lines shown in the figure. It reveals that the brass alloy can be successfully friction stir welded with a very wide range of welding parameters. However, when the welding conditions fall below the lower solid line, the heat input is not sufficient and a defect will be generally formed in the stir zone. As for the welding conditions above the upper solid line, it suggests that the heat input is too much. As a result, superfluous flash and a significant thickness reduction in the stir zone occur. Compared with the process window for the proposed FSW of Al alloys [19], the welding condition to obtain sound welds of the $\mathrm{Cu}-30 \mathrm{Zn}$ brass alloy falls within a much narrower range. However, the FSW of brass alloy shows a similar range of welding parameters to that of the FSW of pure $\mathrm{Cu}[20]$. However, compared with that of the FSW of pure $\mathrm{Cu}$, more heat input is required for the FSW of brass due to its higher strength.

\subsection{Microstructural Characterization}

As a typical example, Fig. 4 shows the microstructural evolution on the cross-sectional plane of a sound weld, which was FSW processed at $200 \mathrm{~mm} / \mathrm{min}$ and $750 \mathrm{rpm}$. In Fig. 4(a), three different zones can be clearly identified, i.e., the stir zone, the TMAZ and the base metal. However, HAZ can not be easily distinguished in the microstructural observations. In the center of the stir zone, a zigzag black line can be found running from the sample surface through the thickness and then down to the center of the bottom. A similar zigzag line has been previously observed in the stir zone of FSW processed Al alloys and was thereafter called the "lazy line" [21, 22]. Although the structure and chemical composition of the lazy line in this study was not investigated, it is believed that the formation mechanism of the "lazy line" during the FSW of a brass alloy should be the same as that in the FSW of an Al alloy. That is, the zigzag line indicated the distribution of the oxide particles, which were formed during the welding process. Fig.4 (b-d) shows the OM images of the different areas marked by 1,2 and 3 in these three different zones at a relatively higher magnification. The base metal consists of very coarse grains with an equiaxial morphology and twins can be clearly distinguished inside some of grains. An obvious boundary between the SZ and TMAZ can be observed and separated by dotted line as shown in Fig. 4(c). In the TMAZ, a mixed microstructure consisting of both coarse grains and fine grains was observed. From the OM image showing the microstructure of the SZ in Fig. 4(d), a rather refined microstructure can be observed and the grains also 
show an equiaxial structure due to the occurrence of dynamic recrystallization.

To reveal the microstructural evolution in the welded region, a large area EBSD map was obtained by the merging of several small area EBSD measurements along the center line of the cross-section across the different specific zones in the joints. The entire EBSD map is shown in Fig. 5(a), which covers three different zones including the base metal, TMAZ and stir zone. Fig. 5(b) shows the IPF map of the base metal, which shows a coarse grain structure and high density of twin structure can be clearly observed. Fig. 5(c) shows the IPF map of the TMAZ, which consists of a mixed microstructure of some coarse grains and fine grains. This mixed microstructure is similar to the so-called "bimodal" grain size distribution of severe plastically deformed and then annealed nanocrystalline pure $\mathrm{Cu}$ [23], in which the micrometer-sized grains were proposed to be formed by abnormal grain growth. Fig. 5(d) shows the IPF map of the stir zone at a higher magnification, which shows a refined microstructure with an equiaxial grain structure. A high density of twins can also be observed. Compared with the twin structure in the base metal, the twins formed in the stir zone have a much thinner twin lamellar width.

From the EBSD measurement, the change in the boundary misorientations of the different zones obtained at $200 \mathrm{~mm} / \mathrm{min}$ and $750 \mathrm{rpm}$ is illustrated in Fig. 6 . The maximum fraction of the angles is located at 60 degrees due to the formation of the annealing twins. For the base metal and the stir zone, the fraction of the low angle boundary is very low. However, the TMAZ shows a much higher fraction of the low angle grain boundary. Since it is believed that increasing the high angle boundary is directly related to the formation of new grains, the stir zone experienced a complete dynamic recrystallization to form new grains. However, for the TMAZ, only a partial dynamic recrystallization occurred due to the less plastic deformation. At the same time, the deformed grains caused by the shear stress may change their grain orientation by grain subdivision or grain rotation during the welding process. As a result, the fraction of the low angle boundary increased. It is also noteworthy that the fraction of the twin boundary also decreased in the TMAZ. However, the stir zone has a much higher fraction of the twin boundary, which also confirmed that the twin boundary in the stir zone was formed by a larger deformation.

Based on the above description, a remarkable refinement of the grain size in the stir zone and that the stir zone exhibits high angle grain boundaries were confirmed. Based on the EBSD measurement in the stir zone, the average grain sizes in the stir zone of the sound welds obtained under different welding conditions were summarized in Table 1, together with that of the base metal. From Table 1, it was noted that at a constant welding speed, the average grain size slightly increases with the increasing tool rotation 
speed. The smallest grain size was about $6.4 \mu \mathrm{m}$, which was obtained in the stir zone of the welds formed at $200 \mathrm{~mm} / \mathrm{min}$ and $750 \mathrm{rpm}$. On the contrary, the largest grain size was about $9.6 \mu \mathrm{m}$, which was obtained in the stir zone of the welds formed at $500 \mathrm{~mm} / \mathrm{min}$ and $1200 \mathrm{rpm}$. For all the welds, the average grain size in the stir zone is much smaller than that of the base metal, which has an average grain size of about $28.2 \mu \mathrm{m}$. The revolutionary pitch is calculated as the division of the welding speed $(\mathrm{mm} / \mathrm{min})$ by the rotation speed (rpm) [24]. According to Table 1, the average grain size in the stir zone increased with the increasing revolutionary pitch, however, only when welded at the same welding speed. Based on all the welds formed under the different welding conditions, the average grain size did not increase linearly with the decreasing revolutionary pitch.

To further investigate the microstructural evolution of the materials after the FSW process, TEM observations of the stir zone as well as the base metal were carried out. Fig. 7(a, b) shows the TEM images of the base metal, in which the twins and low density dislocations were observed as being distributed in the coarse grain structure. Fig. 7(c, d) shows the TEM images of the stir zone welded at $200 \mathrm{~mm} / \mathrm{min}$ and 750 rpm. A high fraction of twins with a thin twin lamellar width and planar dislocations were distributed in the matrix. All the twins and planar dislocations were arrayed parallel to each other within the same single grain. Fig. 7(e, f) shows the TEM images of the stir zone welded at $500 \mathrm{~mm} / \mathrm{min}$ and $1000 \mathrm{rpm}$. The twin lamella thickness is about $200 \mathrm{~nm}$ and its length is in micrometer range, usually limited by the grain size. Although from the EBSD map shown above that the fraction of the twins boundary in the stir zone is less than that of the base metal, it is postulated that the twins lamellar thickness is much smaller than that in the base metals and some twin structure with a thin lamellar width are quite difficult to be detected by EBSD measurement. In Fig. 7(f), a significant amount of dislocations can be found, and the dislocation stack together to form a dislocation cell.

\subsection{Evaluation of Mechanical Properties}

Following the FSW process, tensile tests were carried out to evaluate the mechanical properties of the sound welds. For the global tensile specimen containing the base metal and stir zone, all the specimens fractured in the base metal, indicating the increased tensile strength of the stir zone. In order to evaluate the exact tensile strength of the stir zone, miniature tensile tests of the stir zone were carried out. For the miniature tensile specimen, the gauge area contains only the stir zone of the welds. Fig. 8 (a) shows some of the tensile strain-stress curves of the sound specimen welded under various welding conditions, together 
with that of the base metals. Not all the tensile strain-stress curves are plotted in Fig. 8 (a) for clarity. All the miniature tensile tests results for the sounds welds are summarized in Table 2. It was revealed that all the specimens show a strain hardening stage after yielding. In addition, all the specimens exhibit a higher yielding point and ultimate tensile strength, compared with those of the base metal. The improved tensile strength of the stir zone resulted from the refinement of the microstructure caused by dynamic recrystallization during the welding process. From the appearance of the specimen after the tensile tests shown in Fig.8 (b), the global tensile specimens fractured far from the stirred area, that is, in the base metal, which confirms the higher strength in the stir zone than in the base metals. However, for the miniature tensile specimen, the fraction occurred in the center of the stir zone.

\section{Conclusions}

In this study, the microstructural evolution and mechanical properties of an FSWed $\mathrm{Cu}-30 \mathrm{Zn}$ brass alloy were investigated. Based on the results, the main conclusions are as follows:

1) The optimum friction stir welding condition for the single phase $\mathrm{Cu}-30 \mathrm{Zn}$ brass was obtained at a constant applied load of $1000 \mathrm{~kg}$, which includes a rotation speed that ranged from 750 to $1200 \mathrm{rpm}$, and a welding speed that ranged from 200 to $800 \mathrm{~mm} / \mathrm{min}$.

2) Among all the specimens welded under the different welding conditions, three kinds of welds could be obtained, namely, tunnel-like defects formed in the stir zone due to an insufficient heat input; sound welds; and a superfluous flash formed on the sample surface due to redundant heat input.

3) The FSWed specimens exhibit significantly refined grain size and much denser twins and dislocations in the stir zones. In the TMAZ, a "bimodal" grain size distribution was observed, which contains some coarse grains and remarkably refined grains.

4) All the friction stir welds fractured in the base metal during the tensile tests, indicative of improved mechanical properties in the stir zone. Miniature tensile tests revealed that the highest tensile strength of the stir zone can reach about $380 \mathrm{MPa}$, much higher than the $340 \mathrm{MPa}$ of the base metal.

\section{Acknowledgements:}

The authors wish to acknowledge the financial support of a Collaborative Research Based on Industrial Demand "Heterogeneous Structure Control: Towards Innovative Development of Metallic Structural Materials" by Japan Science and Technology Agency (JST), the Global COE Programs from the Ministry of Education, Sports, Culture, Science, and a Grant-in-Aid for Science Research from the Japan Society for 
Promotion of Science and Technology of Japan, ISIJ Research Promotion Grant.

\section{References:}

[1] W.M. Thomas, International Patent Application No.9125978.8. PCT/GB92 Patent Application. 1991.

[2] L. Cui, H. Fujii, N. Tsuji, K. Nogi, Scr. Mater. 56 (2007) 637-640.

[3] R. Nandan, G.G. Roy, T.J. Lienert, T. Debroy, Acta Mater. 55 (2007) 883-895.

[4] Y. Zhao, Y.S. Sato, H. Kokawa, A.P. Wu, Mater. Sci. Eng. A528 (2011) 7768-7773.

[5] H. Fujii, Y.F. Sun, H. Kato, K. Nakata, Mater. Sci. Eng. A527 (2010) 3386-3391.

[6] K.E. Knipling, R.W. Fonda, Metall. Mater. Trans. A42 (2011) 2312-2322.

[7] P. Periyasamy, B. Mohan, V. Salasubramanian, J. Mater. Eng. Perfor. 21 (2012) 2417-2428.

[8] D.R. Ni, D.L. Chen, D. Wang, B.L. Xiao, Z.Y. Ma, Mater. Des. 51 (2013) 199-205.

[9] R. Nandan, T. DebRoy, H.K.D.H. Bhadeshia, Prog. Mater. Sci. 53 (2008) 980-1023.

[10] R.S. Mishra, Z.Y. Ma, Mater. Sci. Eng. R50 (2005) 1-78.

[11] C. Meran, Mater. Des. 27 (2006) 719-726.

[12] G. Cam, H.T. Serindag, A. Cakan, Mat.-wiss. u. Werkstofftech. 6 (2008) 394-399.

[13] G. Cam, S. Mistikoglu, M. Pakdil, Welding J. 88 (2009) 225s-232s.

[14] G.M. Xie, Z.Y. Ma, L. Geng, Mater. Trans. 49 (2008) 1698-1701.

[15] G.M. Xie, Z.Y. Ma, L. Geng, Phil. Mag. 89 (2009) 1505-1516.

[16] H.S. Park, T. Kimura, T. Murakami, Y. Nagano, K. Nakata, M. Ushio, Mater. Sci. Eng. A371 (2004) 160-169.

[17] M.S. Moghaddam, R. Parvizi, M. Haddad-Sabzevar, A. Davoodi, Mater. Des. 32 (2011) 2749-2755.

[18] Y.G. Kim, H. Fujii, T. Tsumura, T. Komazaki, K. Nakata, Mater. Sci. Eng. A415 (2006) 250-254.

[19] R.S. Mishra, M.W. Mahoney, Friction stir welding and processing. ASM International, 2007

[20] Y.F. Sun, H. Fujii, Mater. Sci. Eng. A527 (2010) 6879-6886.

[21] Y.S. Sato, H. Takauchi, S.H.C. Park, H. Kokawa, Mater. Sci. Eng. A405 (2005) 333-338.

[22] Y.S. Sato, F. Yamashita, Y. Sugiura, S.H.C. Park, H. Kokawa, Scr. Mater. 50 (2004) 365-369.

[23] Y.M. Wang, M.W. Chen, F.H. Zhou, E. Ma, Nature. 419 (2002) 912-915.

[24] H.J. Liu, H. Fujii, M. Maeda, K. Nogi, J. Mater. Proc. Tech. 142 (2003) 692-696. 


\section{Captions of Figures and Tables}

Table 1. Average grain size of the $\mathrm{Cu}-30 \mathrm{Zn}$ brass alloys FSW processed under various conditions.

Table 2. Summaries of the yield strength $\left(\gamma_{\mathrm{s}}\right)$, ultimate strength $\left(\sigma_{u t s}\right)$ and plastic strain $(\varepsilon)$ of the stir zones formed under various welding conditions.

Fig. 1 Three kinds of welding appearances obtained under different conditions. (a) 200 $\mathrm{mm} / \mathrm{min}$ and 500rpm, insufficient heat input; (b) $200 \mathrm{~mm} / \mathrm{min}$ and $750 \mathrm{rpm}$, sound welds; and (c) $200 \mathrm{~mm} / \mathrm{min}$ and $850 \mathrm{rpm}$, redundant heat input.

Fig. 2 Macrostructure observation on the cross-sectional plane of the welds obtained at various welding conditions. (Left: Advancing side; Right: Retreating side.)

Fig.3 FSW processing map for the $\mathrm{Cu}-30 \mathrm{Zn}$ brass alloy.

(×: defects; $\square$ : sound weld; $\triangle$ : overwelded)

Fig. 4 OM images showing the microstructure of the Cu-30Zn FSW processed at $200 \mathrm{~mm} / \mathrm{min}$ and $750 \mathrm{rpm}$. (a) profile; (b) base metal; (c) TMAZ and (d) SZ

Fig. 5 EBSD-IPF maps showing the microstructure of the $\mathrm{Cu}-30 \mathrm{Zn} \mathrm{FSW}$ processed at $200 \mathrm{~mm} / \mathrm{min}$ and 750 rpm. (a) large area IPF map; (b) SZ; (c) TMAZ and (d) base metal.

Fig. 6 Misorientation distribution of the boundary angle in different regions of the welds.

Fig.7 TEM images showing the microstructure of (a, b) base metal and (c, d) stir zone welded at $750 \mathrm{rpm}$ and $200 \mathrm{~mm} / \mathrm{min}$; (e, f) stir zone welded at $1000 \mathrm{rpm}$ and $500 \mathrm{~mm} / \mathrm{min}$.

Fig.8 (a) Miniature tensile strain-stress of the sound-welded specimens; and (b) the appearance of the fractured conventional and miniature specimens 
Table 1. Average grain size of the $\mathrm{Cu}-30 \mathrm{Zn}$ brass alloys FSW processed under various conditions

\begin{tabular}{|c|c|c|c|c|c|c|c|c|}
\hline $\begin{array}{c}\mathrm{mm} / \mathrm{min} \\
(\mathrm{rpm})\end{array}$ & $\begin{array}{c}200 \\
(750)\end{array}$ & $\begin{array}{c}200 \\
(800)\end{array}$ & $\begin{array}{c}350 \\
(950)\end{array}$ & $\begin{array}{c}500 \\
(1000)\end{array}$ & $\begin{array}{c}500 \\
(1200)\end{array}$ & $\begin{array}{c}800 \\
(1100)\end{array}$ & $\begin{array}{c}800 \\
(1200)\end{array}$ & $\begin{array}{c}\text { Base } \\
\text { metal }\end{array}$ \\
\hline $\begin{array}{c}\text { Revolutionary } \\
\text { pitch }(\mathrm{mm} / \mathrm{r})\end{array}$ & 0.267 & 0.25 & 0.368 & 0.5 & 0.417 & 0.727 & 0.667 & - \\
\hline $\begin{array}{c}\text { Average Grain } \\
\text { size }(\mu \mathrm{m})\end{array}$ & 6.4 & 7.2 & 9.4 & 7.1 & 9.6 & 7.7 & 7.8 & 28.2 \\
\hline
\end{tabular}

Table 2. Summaries of the yield strength $\left(\gamma_{s}\right)$, ultimate strength $\left(\sigma_{u t s}\right)$ and plastic strain $(\varepsilon)$ of the stir zones formed under various welding conditions.

\begin{tabular}{|c|c|c|c|c|c|c|c|c|}
\hline $\begin{array}{c}\mathrm{mm} / \mathrm{min} \\
(\mathrm{rpm})\end{array}$ & $\begin{array}{c}200 \\
(750)\end{array}$ & $\begin{array}{c}200 \\
(800)\end{array}$ & $\begin{array}{c}350 \\
(950)\end{array}$ & $\begin{array}{c}500 \\
(1000)\end{array}$ & $\begin{array}{c}500 \\
(1200)\end{array}$ & $\begin{array}{c}800 \\
(1100)\end{array}$ & $\begin{array}{c}800 \\
(1200)\end{array}$ & $\begin{array}{c}\text { Base } \\
\text { metal }\end{array}$ \\
\hline$\gamma_{\mathrm{s}}(\mathrm{MPa})$ & 220 & 210 & 195 & 220 & 190 & 205 & 200 & 125 \\
\hline$\sigma_{\text {uts }}(\mathrm{MPa})$ & 380 & 375 & 360 & 375 & 360 & 360 & 350 & 340 \\
\hline$\varepsilon(\%)$ & 70 & 76 & 84 & 75 & 81 & 68 & 72 & 83 \\
\hline
\end{tabular}



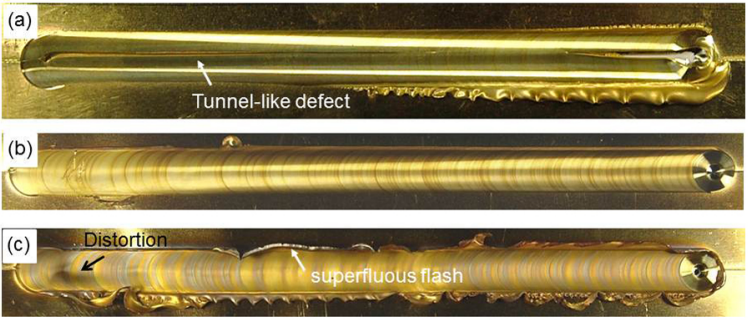

Fig. 1 Three kinds of welding appearances obtained under different conditions. (a) $200 \mathrm{~mm} / \mathrm{min}$ and $500 \mathrm{rpm}$, insufficient heat input; (b) $200 \mathrm{~mm} / \mathrm{min}$ and $750 \mathrm{rpm}$, sound welds; and (c) $200 \mathrm{~mm} / \mathrm{min}$ and $850 \mathrm{rpm}$, redundant heat input. 
$200 \mathrm{~mm} / \mathrm{min} 700 \mathrm{rpm}$

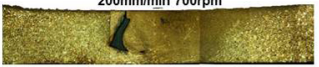

$200 \mathrm{~mm} / \mathrm{min} 750 \mathrm{rpm}$
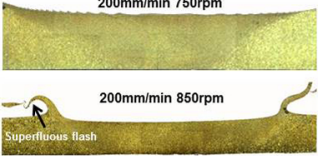

$500 \mathrm{~mm} / \mathrm{min} 850 \mathrm{rpm}$

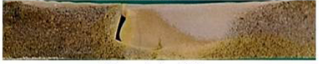

$500 \mathrm{~mm} / \mathrm{min} 1000 \mathrm{rpm}$

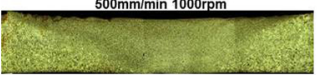

$500 \mathrm{~mm} / \mathrm{min} 1200 \mathrm{rpm}$

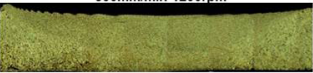

$350 \mathrm{~mm} / \mathrm{min} 800 \mathrm{rpm}$

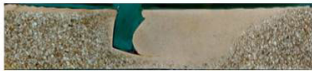

$350 \mathrm{~mm} / \mathrm{min} 900 \mathrm{rpm}$

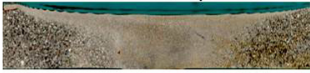

$350 \mathrm{~mm} / \mathrm{min} 950 \mathrm{rpm}$

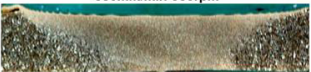

$650 \mathrm{~mm} / \mathrm{min} 1000 \mathrm{rpm}$

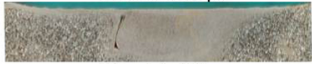

$650 \mathrm{~mm} / \mathrm{min} 1200 \mathrm{rpm}$

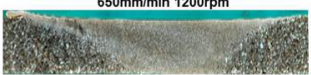

$800 \mathrm{~mm} / \mathrm{min} 1000 \mathrm{rpm}$

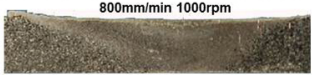

Fig. 2 Macrostructure observation on the cross-sectional plane of the welds obtained at various welding conditions. (Left: Advancing side; Right: Retreating side.) 


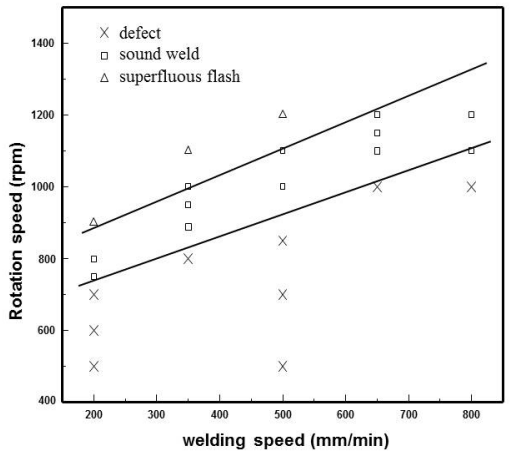

Fig. 3 FSW processing map for the Cu-30Zn brass alloy. ( $x$ : defects; $\square$ : sound weld; $\triangle$ : overwelded) 


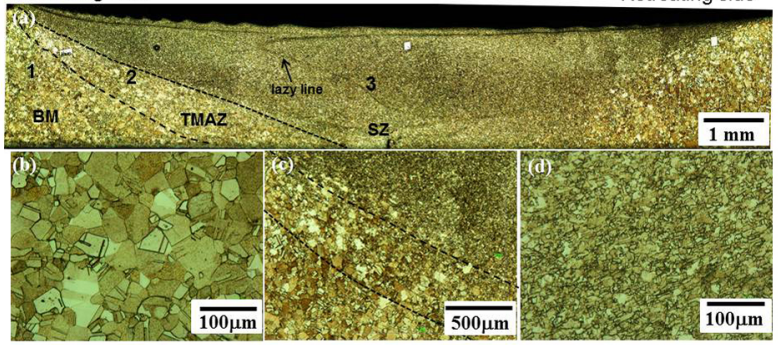

Fig. $4 \mathrm{OM}$ images showing the microstructure of the Cu-30Zn FSW processed at $200 \mathrm{~mm} / \mathrm{min}$ and $750 \mathrm{rpm}$. (a) profile; (b) base metal; (c) TMAZ and (d) SZ 


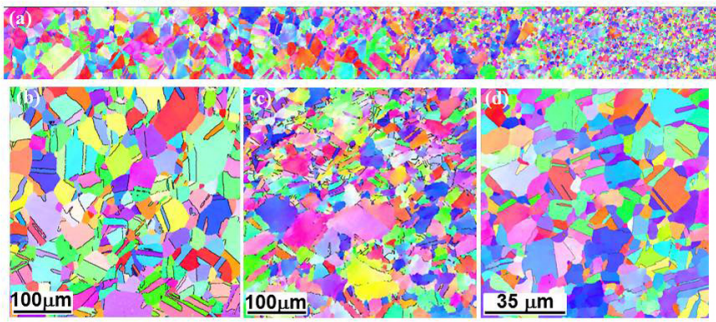

Fig. 5 EBSD-IPF maps showing the microstructure of the Cu-30Zn FSW processed at $200 \mathrm{~mm} / \mathrm{min}$ and $750 \mathrm{rpm}$. (a) large area IPF map; (b) SZ; (c) TMAZ and (d) base metal. 


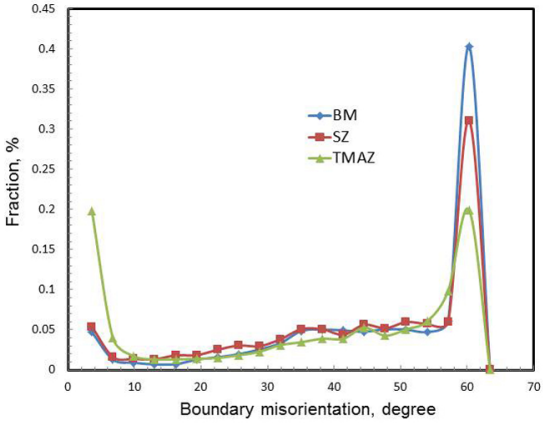

Fig. 6 Misorientation distribution of the boundary angle in different regions of the welds. 

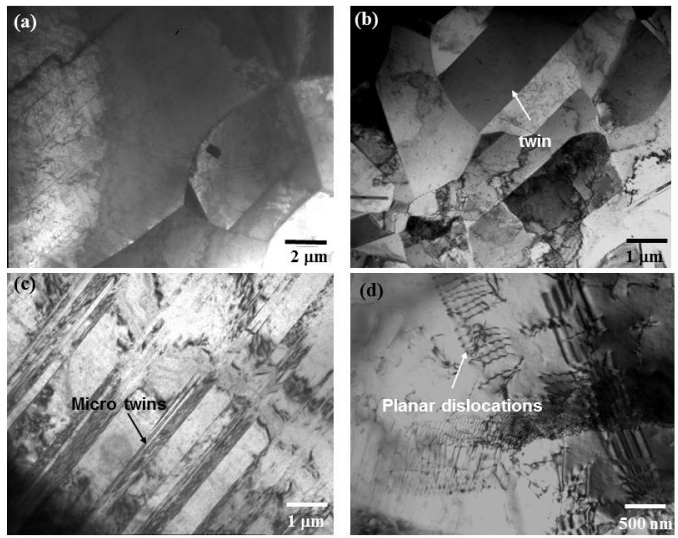

Fig. 7 

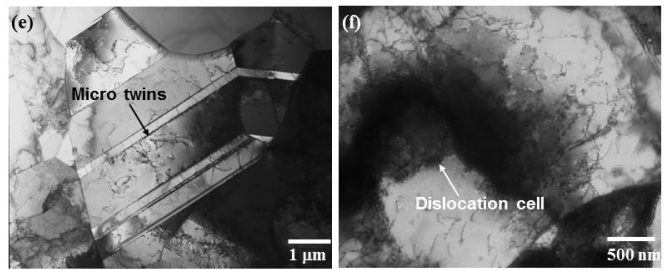

Fig. 7 TEM images showing the microstructure of $(a, b)$ base metal and $(c, d)$ stir zone welded at $750 \mathrm{rpm}$ and $200 \mathrm{~mm} / \mathrm{min}$; (e, f) stir zone welded at $1000 \mathrm{rpm}$ and $500 \mathrm{~mm} / \mathrm{min}$. 


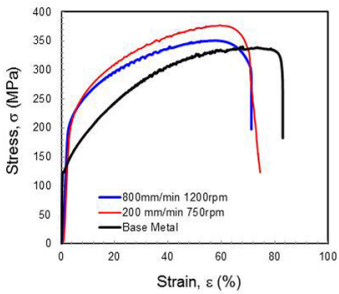

(a)
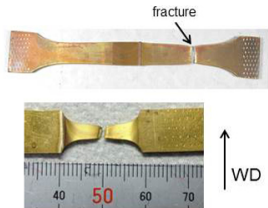

(b)

Fig. 8 (a) Miniature tensile strain-stress of the sound-welded specimens; and (b) the appearance of the fractured conventional and miniature specimens 